\title{
EVALUATION OF SOME BIOPHYSICAL CHARACTERISTICS OF FIVE SILICATE SOLUBILIZING BACTERIA ISOLATED FROM DIFFERENT ECOSYSTEMS
}

\author{
Tran Vo Hai Duong ${ }^{1}$, Nguyen Khoi Nghia ${ }^{2, 凶}$ \\ ${ }^{I}$ Biotechnology Research and Development Institute, Can Tho University, Can Tho City, Vietnam \\ ${ }^{2}$ Department of Soil Science, College of Agriculture, Can Tho University, Can Tho City, Vietnam
}

${ }^{\circledR}$ To whom correspondence should be addressed. E-mail: nknghia@ctu.edu.vn

Received: 26.10 .2019

Accepted: 23.12.2019

\section{SUMMARY}

\begin{abstract}
Silicate solubilizing bacteria (SSB) are key microorganisms to solubilize silicate minerals in the soil. Silicon helps to increase the growth and yield of plants and to enhance the environmental stress tolerance capability of plants. The aim of this study was to evaluate the effect of several factors like $\mathrm{pH}$, salinity, and temperature on silicate solubilizing capacity of five selected SSB. Moreover, phosphorus solubilizing, nitrogen-fixing and indole-3-acetic acid (IAA) synthesizing capacity of these five bacteria were also tested. Liquid soil extract medium containing $0.25 \% \mathrm{Mg}_{2} \mathrm{O}_{8} \mathrm{Si}_{3}$ was used in this study. Abilities of bacteria in phosphorous solubility, nitrogen fixation, and IAA synthesis were tested in NBRIP, Burk's and NBRIP containing $100 \mathrm{mg} \mathrm{L}^{-1}$ tryptophan media, respectively. The results of the study indicated that five SSB showed their high capacity in silicate solubilization at $\mathrm{pH} 7.0, \mathrm{NaCl} 0.0 \%$ and $35^{\circ} \mathrm{C}$. However, at a concentration of $\mathrm{NaCl} 0.5 \%$, these five SSB still solubilized well silicate mineral. Moreover, they also solubilized effectively three different insoluble phosphate sources of $\mathrm{Ca}_{3}\left(\mathrm{PO}_{4}\right)_{2}, \mathrm{AlPO}_{4}$ and $\mathrm{FePO}_{4}$ with a range varied between 105.8 and $928.7 \mathrm{mg} \mathrm{P}_{2} \mathrm{O}_{5} \mathrm{~L}^{-1}, 33.9$ and $49.6 \mathrm{mg} \mathrm{P}_{2} \mathrm{O}_{5} \mathrm{~L}^{-1}$, and 1.94 and $34.1 \mathrm{mg} \mathrm{P}_{2} \mathrm{O}_{5} \mathrm{~L}^{-1}$, respectively. They also fixed biologically nitrogen with a range from 1.37 to $5.09 \mathrm{mg} \mathrm{NH}_{4}^{+} \mathrm{L}^{-1}$ after 2 incubation days. Finally, they also showed their ability in IAA synthesis with an amount between 4.85 and $51.5 \mathrm{mg} \mathrm{IAA} \mathrm{L}^{-1}$. In short, these five SSB in this study not only had the ability in silicate solubilization but also had other functions in plant growth promotion.
\end{abstract}

Keywords: biophysical properties, IAA synthesis, nitrogen fixation, phosphate solubilization, salt concentration, silicate solubilizing bacteria

\section{INTRODUCTION}

Silicon (Si) has been proven to have many benefits for the growth and development of many plant species (Liang et al., 2007). Although the amount of $\mathrm{Si}$ is abundant naturally in the earth's crust, it mostly presents in insoluble forms that cannot be readily absorbed by plant roots. In nature, silicates are solubilized and released into the soil from rocks, minerals by weathering process, the biological activity of plant roots and microorganisms. Among them, silicate solubilizing bacteria (SSB) can play an efficient role in solubilizing insoluble forms of silicates into a soluble form $\left(\mathrm{H}_{4} \mathrm{SiO}_{4}\right)$ to increase soil fertility, plant growth and yield as well as defense mechanisms of plants against pests and diseases (Vasanthi et al.,
2012). Moreover, nitrogen fixation, phosphorus solubilization and IAA synthesis by microorganisms play other important roles in various physiological processes of plants and importantly contribute to enhance plant growth and productivity (Khan et al., 2009). A study of Osman (2009) showed that the vitally important impact of environmental factors like $\mathrm{pH}$, temperature and salt concentration on silicate solubilization of two isolated silicate solubilizing bacteria, Bacillus circulans and Bacillus mucilaginous. In detail, they were able to grow in a wide range of $\mathrm{pH}$, temperature and $\mathrm{NaCl}$ concentration including $7-9,4-45^{\circ} \mathrm{C}$ and $0.25-1.0 \%$, respectively. Furthermore, many studies have focused on the efficient application of silicate solubilizing, nitrogen fixing, phosphate solubilizing and IAA producing bacteria on crop growth and 
yield, however, the studies about the capacity in nitrogen fixation, phosphate solubilization and IAA synthesis of the silicate solubilizing bacteria has still limited. Driving from these matters, the present study was carried out to evaluate influences of some environmental factors on silicate solubilizing ability of five selected bacteria, simultaneously, to test of their nitrogen fixing, phosphate solubilizing and IAA synthesizing capacity.

\section{MATERIALS AND METHODS}

\section{Source of bacteria}

Five isolated silicate solubilizing bacteria including Ochrobactrum ciceri TCM_39 (TCM_39), Microbacterium neimengense $\mathrm{MCM}_{-} 15$ (MCM_15), Klebsiella aerogenes LCT_0 1 (LCT_01), Olivibacter jilunii PTST 30 (PTST_30) and Citrobacter freundii RTTV_12 (RTTV_12) were isolated from intensive bamboo, sugarcane and rice soil samples, as well as earthworm intestine and earthworm feces in sandy soil were used in this study (Tran Vo Hai Duong, Nguyen Khoi Nghia, 2018).

Impact of some environmental factors on the silicate solubilizing capability of five selected SSB under the laboratory conditions

\section{pH}

Bacterial source: bacterial strains were enriched in $100 \mathrm{~mL}$ flasks containing $20 \mathrm{~mL}$ TSB medium in 3 days. The TSB medium composition in $1 \mathrm{~L}$ included $30 \mathrm{~g}$ tryptone soya broth in $1 \mathrm{~L}$ distilled water. The bacterial broth culture suspension after incubation was aseptically transferred into sterilized $50 \mathrm{~mL}$ Falcon tube, centrifuged at $6,000 \mathrm{rpm}$ in 5 mins, discarded the supernatant, refilled with $20 \mathrm{~mL}$ sterilized distilled water and repeated this whole procedure for another 3 times. Finally, bacterial pellet was adjusted to $\mathrm{OD}_{600 \mathrm{~nm}}=0.7$ with sterilized MQ water by Multiskan Spectrum spectrophotometer (Thermo Scientific). Additionally, bacterial source prepared for evaluating salt content, temperature, phosphorous solubility, nitrogen fixation and IAA synthesis was carried out as the same manner.

Experimental design: Experiment was performed in sterilized $250 \mathrm{~mL}$ Erlenmeyer flask containing $100 \mathrm{ml}$ mineral salt medium supplying $0.25 \%$ magnesium trisilicate (medium composition contained $1.0 \mathrm{~g}$ glucose, $0.5 \mathrm{~g} \mathrm{~K}_{2} \mathrm{HPO}_{4} .3 \mathrm{H}_{2} \mathrm{O}, 100$ $\mathrm{mL}$ soil extract, $900 \mathrm{~mL}$ distilled water, and $\mathrm{pH}$ of 7.0-7.2. Besides, soil extract solution was prepared by collecting approximately $40 \mathrm{~g}$ of soil and then added $50 \mathrm{~mL}$ of water and stirred for 20 mins. The slurry was allowed to settle down, then filtered firstly through a Kimwipe tissue, and after that, the filtrate was passed through a Number 1 Whatman filter paper placed on a funnel (Bold, 1949). Four treatments including $\mathrm{pH} 3, \mathrm{pH} 5, \mathrm{pH} 7$ and $\mathrm{pH} 9$ were established. Each treatment had 3 replicates and each $\mathrm{pH}$ level treatment had a control treatment without microbial inoculation. To prevent fungi growth and contamination, the liquid medium was added with 10 $\mathrm{mg} \mathrm{L}^{-1}$ Vimetatin 56 fungicides after autoclaving. An aliquot of one $\mathrm{ml}$ of prepared bacterial suspension

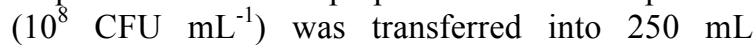
sterilized Erlenmeyer flask. The flasks were incubated at $30 \pm 2^{\circ} \mathrm{C}$ on rotary shaking incubator (120 rpm) for 10 days in the dark as described by Sheng et al. (2008). Soluble Si concentration in liquid medium was determined at day $0,2,4,6,8$ and 10. The method for determining soluble concentration of $\mathrm{Si}$ in liquid medium was adopted from Hallmark et al. (1982) as following procedure: firstly, transferred one $\mathrm{ml}$ of bacterial suspension into $50 \mathrm{~mL}$ Falcon tube, after that $2.5 \mathrm{~mL}$ of $20 \%$ ammonium acetate were added into each tube, capped tightly, and shook vigorously for $10 \mathrm{sec}$, uncapped and added $1.0 \mathrm{~mL}$ of $0.3 \mathrm{M}$ ammonium molybdate into each tube. After 5 minutes for

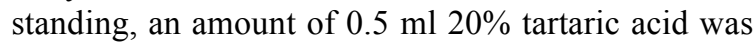
added into each tube, capped tightly and shook vigorously to thoroughly mix reagents, uncapped, added $0.5 \mathrm{~mL}$ reducing solution including $2 \mathrm{~g}$ $\mathrm{Na}_{2} \mathrm{SO}_{3}, 0.4 \mathrm{~g} \mathrm{C}_{10} \mathrm{H}_{9} \mathrm{NO}_{4} \mathrm{~S}$ and $25 \mathrm{~g} \mathrm{NaHSO}_{3}$ in 250 $\mathrm{mL}$ distilled water, capped tightly and again shook vigorously. Finally, samples were diluted to a final volume of $7.5 \mathrm{~mL}$ with $20 \%$ acetic acid solution, capped and shook well. To develop the color of samples, samples were left for 60 minutes at room temperature and tubes were shaken vigorously to mix well prior to determining absorbance using a spectrophotometer calibrated at $815 \mathrm{~nm}$. A series of the diluted standard solution of Si were prepared by adding $0,40,80,120,160$ and $200 \mu \mathrm{L}$ of $100 \mathrm{mg} \mathrm{L}^{-1}$ Si standard solution to $7.5 \mathrm{~mL}$ polyethylene tubes and all reagents were added into the standard solution as the same manners as the real samples as described above.

\section{NaCl concentration}

To evaluate the impact of the salt content of liquid medium on $\mathrm{Si}$ solubilization capacity of five selected SSB, an experiment was conducted in the 
same manner as the $\mathrm{pH}$ experiment. However, liquid minimal salt medium including different $\mathrm{NaCl}$ concentration $(0 \%, 0.15 \%, 0.3 \%$ and $0.5 \% \mathrm{NaCl})$ were considered as different treatments.

\section{Temperature}

To assess the impact of different ambient air temperature on $\mathrm{Si}$ solubilization capacity of five selected SSB, an experiment was conducted as the manner as the $\mathrm{pH}$ experiment. However, different ambient air temperatures of 25,35 and $45^{\circ} \mathrm{C}$ used to incubate the bacteria were considered as different treatments.

\section{Phosphorous solubilizing, nitrogen-fixing and IAA synthesizing capacity of five selected SSB}

\section{Phosphate solubilizing capability}

Phosphate solubilizing capability of five SSB was performed with 3 different insoluble phosphate mineral sources including $\mathrm{Ca}_{3}\left(\mathrm{PO}_{4}\right)_{2}, \mathrm{FePO}_{4}$ and $\mathrm{AlPO}_{4}$ as considered as three different treatments. An aliquot of one $\mathrm{ml}$ already prepared bacterial solution $\left(10^{8} \mathrm{CFU} \mathrm{mL}^{-1}\right)$ was transferred into sterilized $250 \mathrm{~mL}$ Erlenmeyer flask containing 100 $\mathrm{mL}$ liquid NBRIP medium. The NBRIP medium composition in $1.01\left(\mathrm{~g} . \mathrm{l}^{-1}\right)$ contained $10 \mathrm{~g}$ glucose; 5.0 g $\mathrm{Ca}_{3}\left(\mathrm{PO}_{4}\right)_{2} ; \quad 5.0$ g $\mathrm{MgCl}_{2} .6 \mathrm{H}_{2} \mathrm{O} ; 0.25 \mathrm{~g}$ $\mathrm{MgSO}_{4} .7 \mathrm{H}_{2} \mathrm{O} ; 0.2 \mathrm{~g} \mathrm{KCl}$ and $0.1 \mathrm{~g}\left(\mathrm{NH}_{4}\right)_{2} \mathrm{SO}_{4}$ and $\mathrm{pH}=7.0$. All samples were incubated at $30 \pm 2^{\circ} \mathrm{C}$ on an orbital shaker $(120 \mathrm{rpm})$ for 10 days in the dark under the laboratory conditions. Soluble phosphate concentration in liquid medium was determined as phosphomolypdate method at day $0,2,4,6,8$ and 10. An aliquot of five $\mathrm{ml}$ bacterial suspension was filtered through a syringe with a $0.45 \mu \mathrm{m}$ membrane filter before phosphate analysis. Two $\mathrm{mL}$ of bacterial suspension were transferred into $2 \mathrm{~mL}$ Eppendorf, centrifuged at $14,000 \mathrm{rpm}$ in 5 mins, harvested the bacterial pellet, performed 10 fold diluted solution series with deionized water, after that, an aliquot of 5 $\mathrm{mL}$ of solution was put into sterilized $30 \mathrm{~mL}$ test tube, added $1 \mathrm{~mL}$ B solution (Sample: B solution with a ratio of $5: 1(\mathrm{v} / \mathrm{v}))$, mixed well in $1 \mathrm{~min}$ with vortex, left the samples at room temperature for 30 mins, and finally soluble phosphate concentration was determined at $880 \mathrm{~nm}$ by spectrophotometer.

\section{Nitrogen-fixing capacity}

An aliquot of one $\mathrm{ml}$ already prepared bacterial suspension $\left(10^{5} \mathrm{CFU} \mathrm{mL} \mathrm{mL}^{-1}\right)$ was transferred into 250 $\mathrm{mL}$ sterilized Erlenmeyer flask containing $100 \mathrm{ml}$ Burk's medium. N-free Burk's medium containing following ingredients $\left(\mathrm{g} \mathrm{L}^{-1}\right) 20.0 \mathrm{~g}$ sucrose; $0.64 \mathrm{~g}$ $\mathrm{K}_{2} \mathrm{HPO}_{4} ; 0.16 \mathrm{~g} \mathrm{KH}_{2} \mathrm{PO} 4 ; 0.20 \mathrm{~g} \mathrm{MgSO}_{4} ; 0.20 \mathrm{~g}$ $\mathrm{NaCl} ; 0.05 \mathrm{~g} \mathrm{CaSO}_{4} .2 \mathrm{H}_{2} \mathrm{O} ; 5.0 \mathrm{~mL} \mathrm{Na} \mathrm{MoO}_{4} .2 \mathrm{H}_{2} \mathrm{O}$ $(0.05 \%) ; 5.0 \mathrm{~mL} \mathrm{FeSO}_{4} .7 \mathrm{H}_{2} \mathrm{O}(0.3 \%)$ and $\mathrm{pH}=7.0$. All samples were incubated at $30 \pm 2{ }^{\circ} \mathrm{C}$ on an orbital shaker $(120 \mathrm{rpm})$ for 10 days in the dark under the laboratory conditions. Nitrogen amount fixed by bacteria in liquid medium was determined at day 1 , $2,3,4$, and 5 . One $\mathrm{mL}$ of bacterial suspension was transferred into $2 \mathrm{~mL}$ Eppendorf, centrifuged at $12,000 \mathrm{rpm}$ in $5 \mathrm{mins}$, took an amount of $0.5 \mathrm{~mL}$ supernatant into $50 \mathrm{~mL}$ Falcon, added successively 2 $\mathrm{mL}$ of deionized water, $0.5 \mathrm{~mL}$ EDTA, $1 \mathrm{~mL}$ Nitroprusside and $2 \mathrm{~mL}$ Sodium hypochloride into each Falcon tube, mixed well the samples by vortex in $1 \mathrm{~min}$ and then left the samples at the room temperature for 30 mins and finally, the amount of nitrogen concentration was determined at $636 \mathrm{~nm}$ by a spectrophotometer.

\section{Indole-3-Acetic Acid (IAA) synthesizing capacity}

The experiment was conducted in a $100 \mathrm{~mL}$ flask with 3 replicates corresponding to 3 incubation flasks. An aliquot of one $\mathrm{mL}$ of prepared bacterial

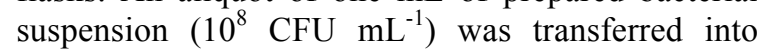
flasks containing $29 \mathrm{~mL}$ liquid NBRIP medium with supplementation of $100 \mathrm{mg} \mathrm{L}^{-1}$ tryptophan. All samples were incubated at $30 \pm 2^{\circ} \mathrm{C}$ in a rotary shaker at $120 \mathrm{rpm}$ for 10 days in the dark and under the laboratory conditions. Synthesized IAA concentration by bacteria in liquid medium was determined at day $0,2,4,6,8,10$, and 12. An aliquot of bacterial suspension $(1.5 \mathrm{~mL})$ was transferred into $2 \mathrm{~mL}$ Eppendorf, centrifuged at $13,000 \mathrm{rpm}$ in 10 mins, then transferred $1 \mathrm{~mL}$ supernatant into test tubes containing $2 \mathrm{~mL} \mathrm{R} 2$ reagent, mixed well the solution with vortex, left the samples at room temperature for $10 \mathrm{~min}$ in the dark, finally the synthesized IAA concentration in liquid medium was determined at $530 \mathrm{~nm}$ by spectrophotometer. The composition of one litter of $\mathrm{R} 2$ reagent containing 1 $\mathrm{L} \mathrm{H}_{2} \mathrm{SO}_{4} 10.8 \mathrm{M}$ and $4.5 \mathrm{~g} \mathrm{FeCl}_{3}$.

\section{Data analysis}

The data was processed with Microsoft Office Excel 2013 and SPSS 22.0 software.

\section{RESULTS}

\section{Impact of different pH levels of liquid medium on silicate solubilizing capacity of five silicate solubilizing bacteria}

The impact of $\mathrm{pH}$ of the medium on silicate 
solubilization capacity of five selected SSB (PTST 30, LCT 01, RTTV 12, TCM 39 and MCM_15) presented in Fig. $\overline{1}$ indicated that the silicate concentrations of all $\mathrm{pH}$ treatments of five bacteria had the same pattern as the concentration of $\mathrm{Si}$ in the liquid medium increased steadily at the stage of 0-4 days of incubation then dramatically increased on day 4, and lasted until day 6. The highest peak of $\mathrm{Si}$ concentration in liquid medium was detected at day 6 and then decreased quickly afterward until the end of the experiment. For all bacteria tested, soluble silicate concentrations were found to be highest almost on day 6. Moreover, all five bacteria showed their best silicate solubilizing capability in the treatments with $\mathrm{pH} 7$ where the highest silicate concentrations reached between 32.3 and $54.9 \mathrm{mg} \mathrm{L}^{-1}$. Furthermore, the concentration of $\mathrm{Si}$ dissolved by five bacteria was still high in treatments with $\mathrm{pH}$ of 3, 5, and 9. The soluble silicate concentrations dissolved by five SSB in treatments with $\mathrm{pH} \mathrm{3,5}$ and 9 were varied between 9.86 and $23.9 \mathrm{mg} \mathrm{L}^{-1}, 20.2$ and $35.7 \mathrm{mg} \mathrm{L}^{-1}$, and 13.2 and $1.5 \mathrm{mg} \mathrm{L}^{-1}$, respectively. As taking into account to compare treatments having the same $\mathrm{pH}$ level in the liquid medium but different bacteria with each other, the result showed that there was not much difference about silicate concentrations at any sampling time.
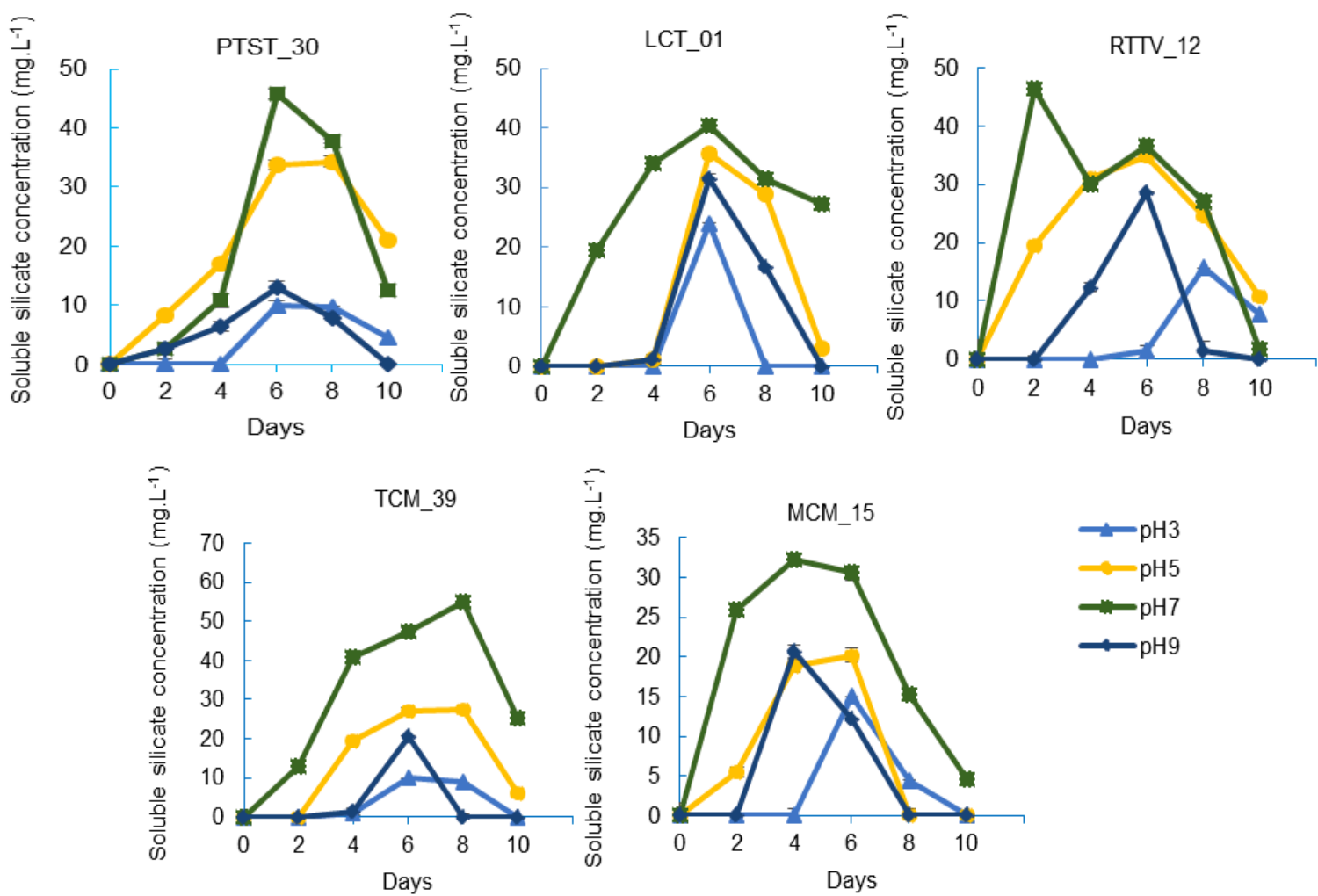

Figure 1. Silicate concentrations solubilized by five bacteria in different $\mathrm{pH}$ treatments.

Influence of different $\mathrm{NaCl}$ concentrations of liquid medium on silicate solubilization capacity of five silicate solubilizing bacteria

Silicate concentrations solubilized by five bacteria, PTST_30, LCT_01, RTTV_12, TCM_39, and MCM_15, in different treatments containing different salt contents $(0,0.15,0.3$ and $0.5 \%)$ were presented in Fig. 2. The results showed that there was a rapid increase of the silicate concentrations in the liquid medium in the time period of 0-6 days of incubation, reached the highest peak of the concentration on day 6 and after this day, the concentration of silicate was dropped strongly until the end of the experiment. In addition, most of the five bacteria showed their significant highest capacity in silicate solubilization in the treatments without $\mathrm{NaCl}$ addition where silicate concentrations 
varied between 37.5 and $53.7 \mathrm{mg} \mathrm{L}^{-1}$. Moreover, a negative correlation between the soluble silicate concentrations and the concentration of $\mathrm{NaCl}$ in liquid medium was also found. This means that the concentrations of silicate in the liquid medium dissolved by bacteria from Si mineral were reduced when increasing concetration of $\mathrm{NaCl}$ in the liquid medium. However, these five bacteria still had good silicate solubilization capacity in liquid medium containing $\mathrm{NaCl}$ up to $0.5 \%$ and the highest soluble silicate concentration of the five bacteria varied between 12.5 and $17.7 \mathrm{mg} \mathrm{L}^{-1}$. Moreover, no much difference about silicate concentrations in the liquid medium at any sampling time among treatments owning the same concentration of $\mathrm{NaCl}$ in the liquid medium regardless of bacteria.
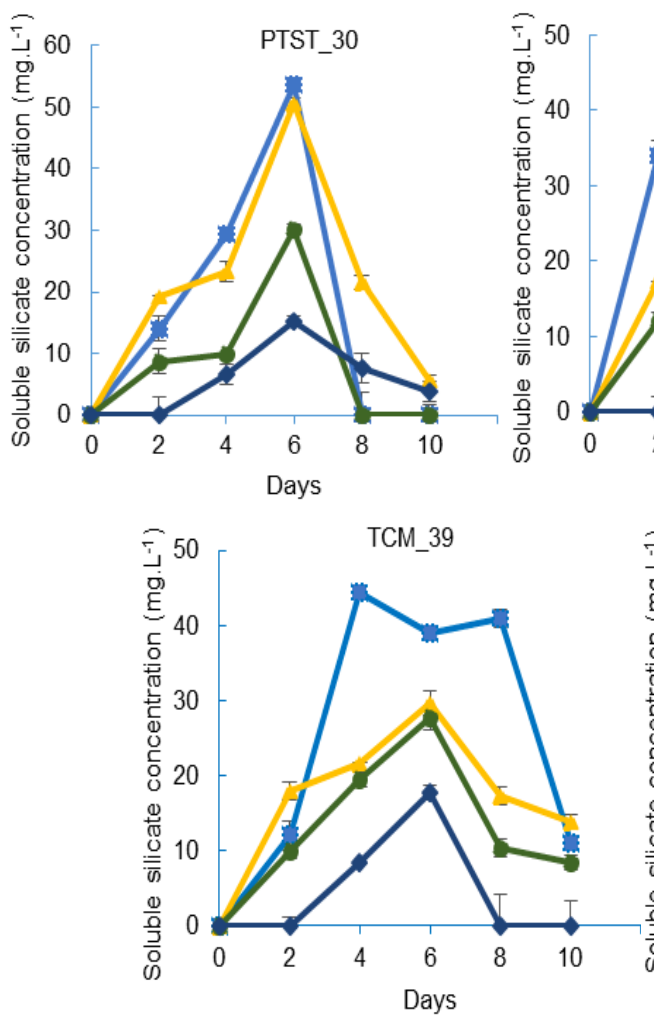
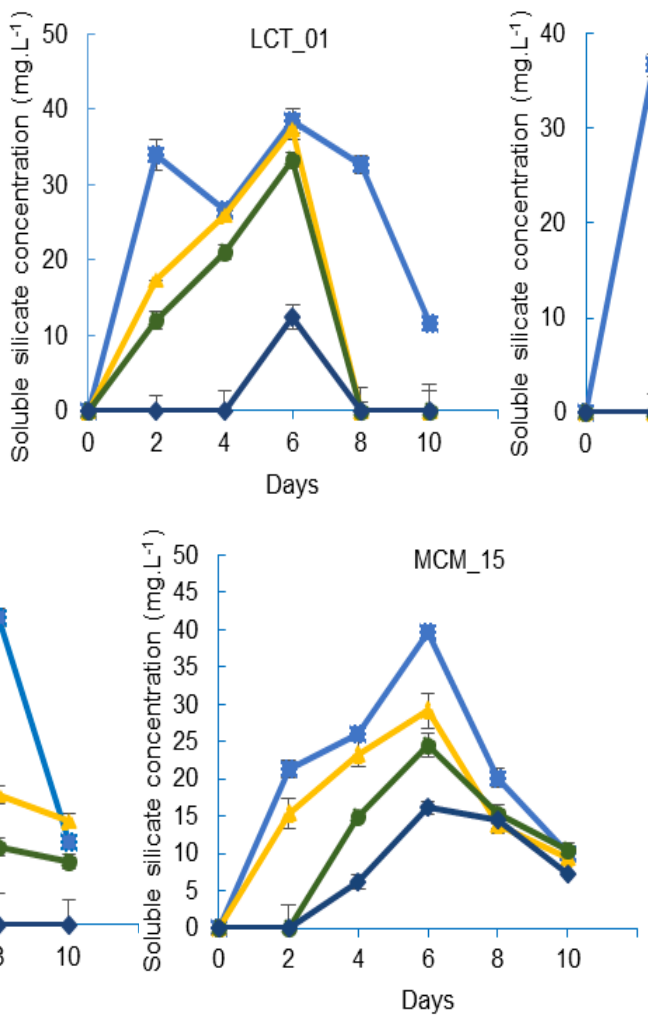
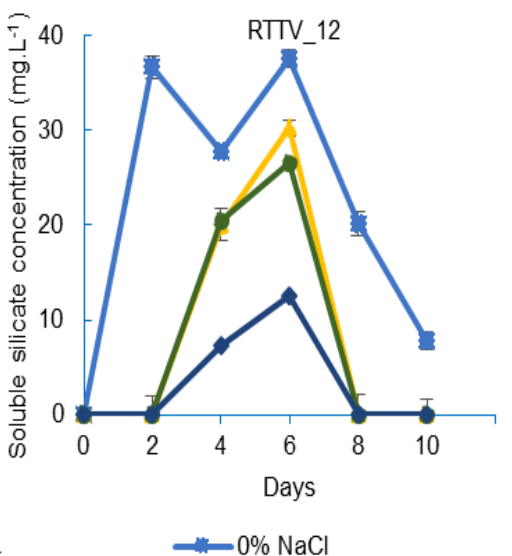

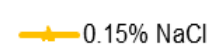

$-0.3 \% \mathrm{NaCl}$

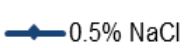

Figure 2. Silicate concentrations solubilized by five bacteria in different $\mathrm{NaCl}$ concentration treatments

\section{Impact of different ambient air temperatures on silicate solubilization capacity of five silicate solubilizing bacteria}

The results of the experiment in testing the influence of different ambient air temperature levels on silicate solubilizing capability of PTST_30, LCT_01, RTTV_12, TCM_39, and MCM_15 were presented in Fig. 3 and showed that the silicate concentrations of most treatments increased sharply in the time period of $0-6$ days of incubation, achieved the highest peaks on day 6 , and then decreased strongly afterward until the end of the experiment. When comparing treatments among the same bacteria, the results showed that the highest and significant silicate concentrations were found in treatments with temperature of $35^{\circ} \mathrm{C}$ and the highest concentrations of silicate in liquid medium on day 6 of PTST 30, LCT 01, RTTV 12, TCM 39, and MCM 15 were $47 . \overline{2}, 42.0,38.5,52.1$, and $39.0 \mathrm{mg}$ $\mathrm{L}^{-1}$, respectively. Moreover, these five strains still had fairly good solubilizing capacity either under the environmental temperature of $25^{\circ} \mathrm{C}$ or $45^{\circ} \mathrm{C}$ with a range between 17.3 and $46.3 \mathrm{mg} \mathrm{L}^{-1}$ and between 25.5 and $36.4 \mathrm{mg} \mathrm{L}^{-1}$, respectively. The lowest concentration of soluble $\mathrm{Si}$ in liquid medium was found in the treatment with $45^{\circ} \mathrm{C}$. It was found that there was not much difference in silicate 
concentrations at any sampling time among treatments having the same ambient air temperature regardless of bacteria.

\section{Phosphate solubilizing capability of five silicate solubilizing bacteria}

The results from the experiments in testing phosphate-solubilizing capacity of PTST_30, LCT_01, RTTV_12, TCM_39, and MCM_15 were presented in Fig. 4 and indicated that for most of the bacteria, there was a rapid increase of phosphorus concentrations in liquid medium of treatments containing $\mathrm{Ca}_{3}\left(\mathrm{PO}_{4}\right)_{2}$ in a time period 0-6 days of incubation, reached the highest concentrations at day 4 or day 6 , depending on bacteria, but mainly day 6 and then decreased gradually until end of the experiment. Almost five bacteria had a low capacity in phosphate solubilization for $\mathrm{AlPO}_{4}$ and $\mathrm{FePO}_{4}$ phosphate sources. The concentration of soluble phosphorus in liquid medium was found to be varied between 33.9 and $49.6 \mathrm{mg} \mathrm{L}^{-1}$ and between 1.94 and $34.1 \mathrm{mg} \mathrm{L}^{-1}$ for $\mathrm{AlPO}_{4}$ and $\mathrm{FePO}_{4}$ phosphate sources, respectively, after 6 days of incubation. The highest phosphorous concentrations were found in treatments containing $\mathrm{Ca}_{3}\left(\mathrm{PO}_{4}\right)_{2}$ as phosphorous source with a big variation of phosphorous concentrations among bacteria (between 106 and 929 $\mathrm{mg} \mathrm{L}^{-1}$ after 6 days of incubation). There was a significant difference $(p<0.05)$ among bacteria about phosphorus-solubilizing capacity in treatments containing $\mathrm{Ca}_{3}\left(\mathrm{PO}_{4}\right)_{2}$ as phosphorous source. The phosphate solubilization capacity of five tested bacteria in liquid medium containing $\mathrm{Ca}_{3}\left(\mathrm{PO}_{4}\right)_{2}$ as phosphorous source was ranked as following orders: LCT_01 > TCM_39>MCM_15 > RTTV_12 > PTST_30 with a corresponding amount of 929,781 , $651, \overline{565}$, and $106 \mathrm{mg} \mathrm{L}^{-1}$, respectively.
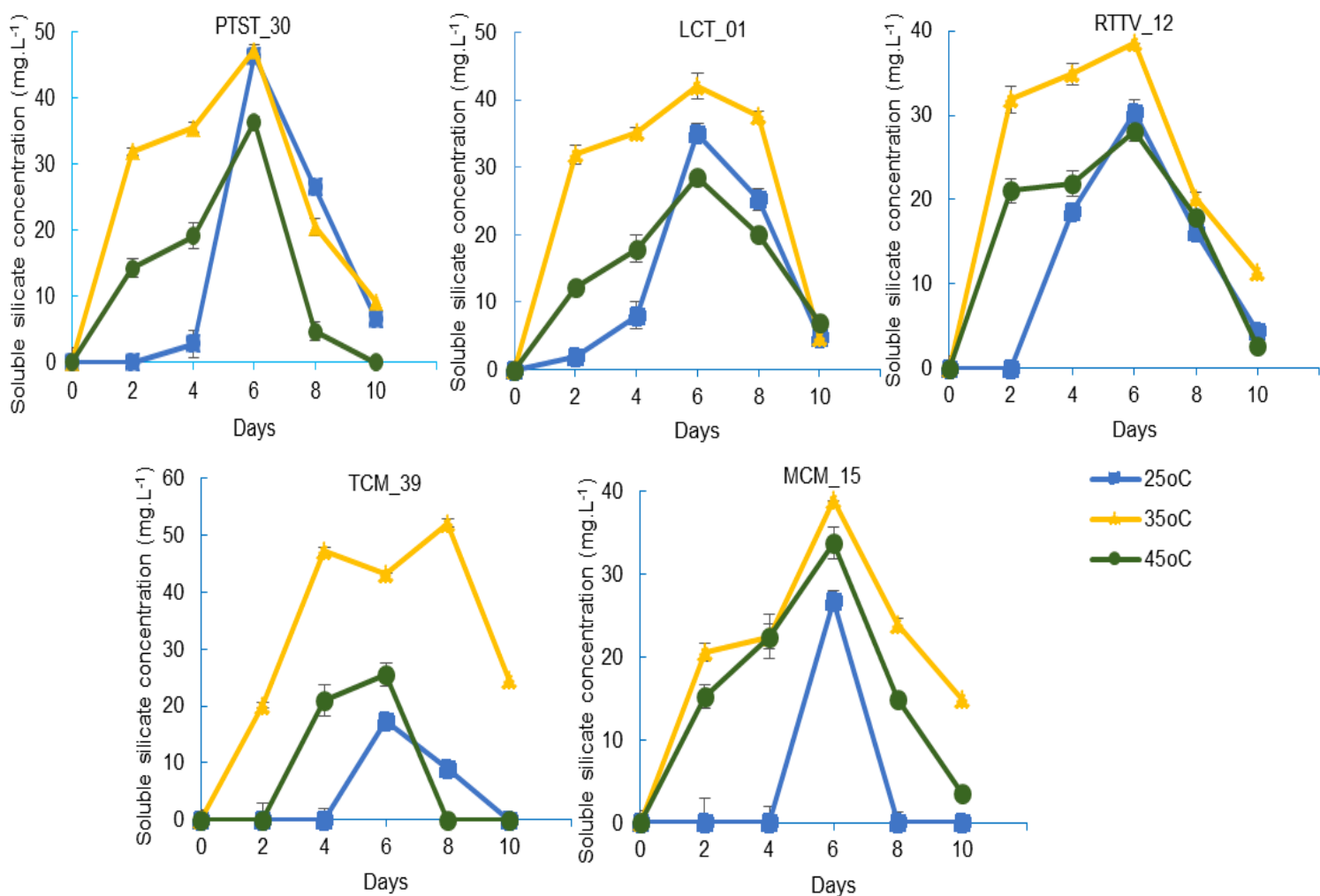

Figure 3. Silicate concentrations solubilized by five bacteria in different ambient air temperature treatments.

\section{Nitrogen-fixing capacity of five silicate solubilizing bacteria}

The results from the experiment in testing the biological nitrogen-fixing capacity of PTST 30 , LCT_01, RTTV_12, TCM_39, and MCM_15 were presented in Fig. $\overline{5}$ and indicated that all five bacteria had a capacity to fix nitrogen biologically and the 
available nitrogen concentrations fixed by five bacteria tended to increase gradually in the first two or three days, but mainly within two days, reached the highest points on day 2 or day 3 and then dropped strongly afterwards. Additionally, the highest fixed nitrogen concentrations of five bacteria
(PTST_30, LCT_01, RTTV_12, TCM_39 and MCM_15) at day 2 or day 3 were ranked as following orders: PTST $30>$ TCM $39>$ MCM 15 $>$ RTTV $12>$ LCT 01 with an corresponding amount of $5.09,3.87,2.75,1.75$ and $1.37 \mathrm{mg} \mathrm{L}^{-1}$, respectively.
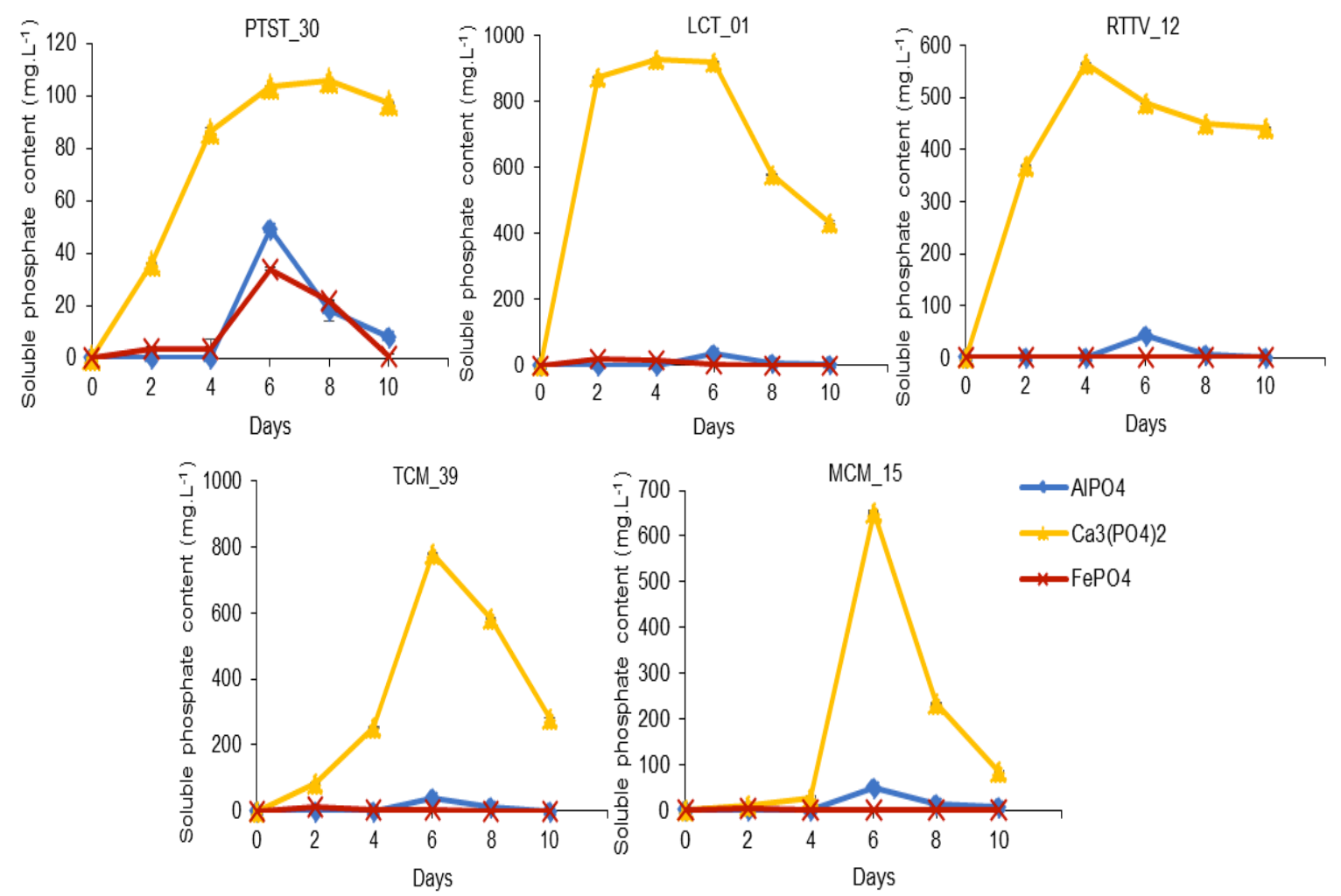

Figure 4. Phosphate concentrations solubilized by five silicate-solubilizing bacteria in different phosphorous source treatments.

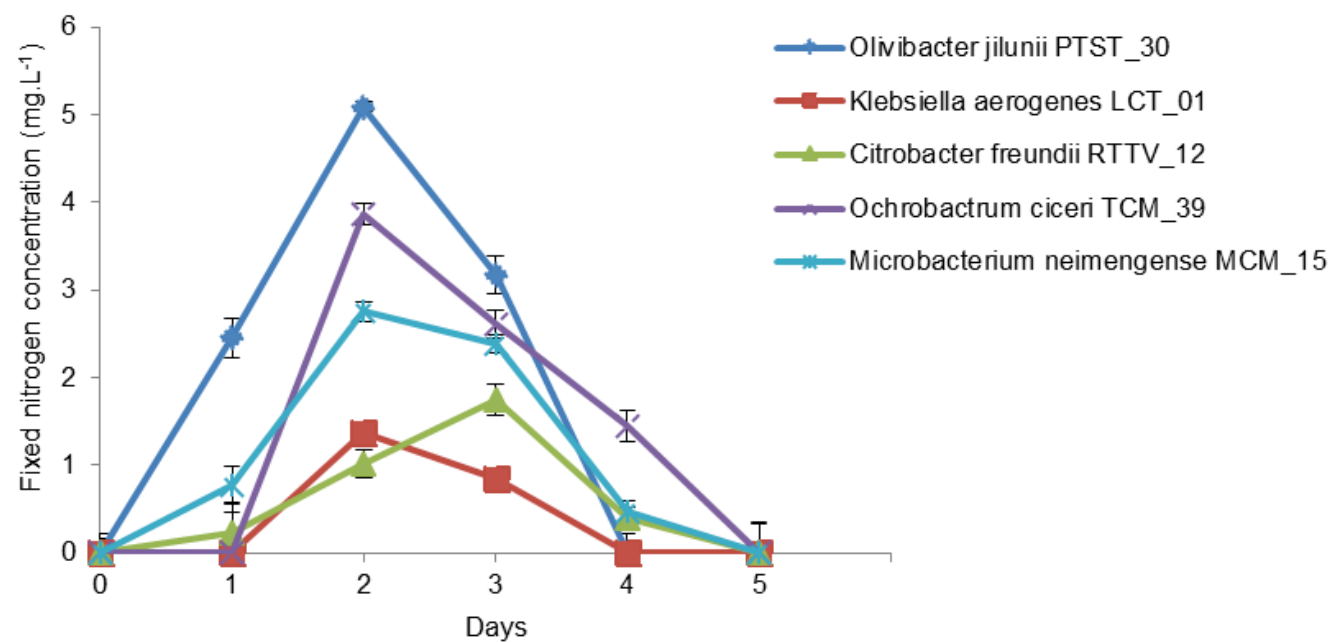

Figure 5. Available nitrogen concentrations fixed by five silicate solubilizing bacteria in Burk liquid medium. 


\section{IAA-synthesizing capacity of five silicate solubilizing bacteria}

Figure 6 presented the amounts of phytohormone IAA produced by five different bacteria in liquid medium containing $100 \mathrm{mg} \mathrm{L}^{-1}$ tryptophan. All five bacteria named as PTST 30, LCT 01, RTTV 12, TCM 39, and MCM_15 showed their capacity in IAA synthesis in the liquid medium. The highest concentrations of IAA produced by bacteria in liquid medium were detected on day 2 and day 8 . At day 2 only two bacteria, LCT_01 and RTTV_12 could produce IAA with a concentration recorded as 27.9 and $19.6 \mathrm{mg} \mathrm{L}^{-1}$, respectively whereas three other bacteria did not produce any IAA production. On day
4 , the concentrations of IAA produced by these two bacteria were decreased strongly. On day 6, three other bacteria started to produce IAA with an IAA production varied between $2.39 \mathrm{mg} \mathrm{L}^{-1}$ IAA and 6.79 $\mathrm{mg} \mathrm{L}^{-1}$ IAA. At day 8 the concentrations of IAA produced by all five bacteria were recorded as the highest peak of IAA concentration during the experimental time. Among five bacteria tested, LCT_01 strain produced highest amount of IAA production with an amount of $51.5 \mathrm{mg} \mathrm{L}^{-1}$, followed by RTTV_12 with a concentration of $17.7 \mathrm{mg} \mathrm{L}^{-1}$ while three other bacteria, PTST_30, MCM_15, and TCM_39 synthesized lower amounts of IAA production of $12.1,11.3$ and $3.8 \mathrm{mg} \mathrm{L}^{-1}$ IAA, respectively.

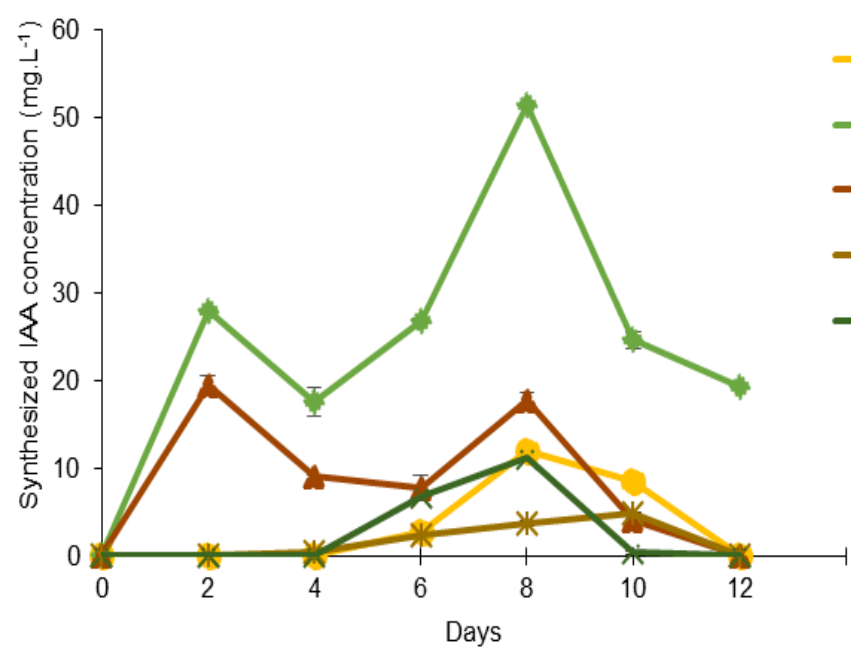

Figure 6. Phytohormone IAA concentrations synthesized by five different silicate-solubilizing bacteria in liquid medium.

\section{DISCUSSION}

The results of this study revealed that under the conditions of environment like neutral $\mathrm{pH} 7, \mathrm{NaCl}$ $0.0 \%$ and temperature of $35^{\circ} \mathrm{C}$ the silicatesolubilizing efficiency of all five SSB was outstandingly promoted. Moreover, these five bacteria were genetically identified as Microbacterium neimengense MCM_15, Olivibacter jilunii PTST_30, Citrobacter freudii RTTV_12, Klebsiella aerogenes LCT_01, and Ochrobactrum ciceri TCM 39. From many previous studies, it was showed that Microbacterium neimengense, Olivibacter jilunii and Citrobacter freudii grew better under conditions of environment like $\mathrm{pH}$ range of $7.0-7.2,3 \%$ salt content $(\mathrm{NaCl})$, and at $37^{\circ} \mathrm{C}$ temperature (Gao et al., 2013), $\mathrm{pH}$ of $6,0-9,0,5.0 \%$
$\mathrm{NaCl}$ and $4-42^{\circ} \mathrm{C}$ temperature (Chen et al., 2013) and $\mathrm{pH}$ of $6,5,3,0-4,5 \% \mathrm{NaCl}$ and $37^{\circ} \mathrm{C}$ temperature (Keevil et al., 1977; Jacob, Irshaid, 2012). However, there were not many studies about the influence of $\mathrm{pH}$, salt content and temperature on Klebsiella aerogenes and Ochrobactrum ciceri. Moreover, in a study of Hadi et al. (2013) showed that Ochrobactrum ciceri grew better under the temperature of $30^{\circ} \mathrm{C}$.

In addition, all five bacteria revealed their high capacity in phosphate solubility in the liquid medium. This could be due to these bacteria could produce organic acids such as gluconic acid, lactic acid, succinic acid, formic acid, malic acid, citric acid, oxalic acid, acetic acid or tartaric acid. These organic acids could help to dissolve efficiently not 
only the insoluble silicate minerals but also insoluble phosphate minerals and become the soluble one for bacteria and plant to absorb for their growth (Khan et al., 2014) and the outcome of the previous studies showed that Citrobacter freundii had another function in phosphate solubilization in liquid medium containing $\mathrm{Ca}_{3}\left(\mathrm{PO}_{4}\right)_{2}$ as phosphorus source and Klebsiella aerogenes as well in phosphate solubilization (Toribio-Jiménez et al., 2017; Samina et al., 2010). However, these bacteria's function in phosphate solubilization for $\mathrm{AlPO}_{4}$ and $\mathrm{FePO}_{4}$ as phosphorous sources for bacteria has still not published yet. Moreover, the function in phosphate solubilization of Microbacterium neimengense, Olivibacter jilunii and Ochrobactrum ciceri has also still not published yet.

For the nitrogen-fixing capability of these five strains, it was found that the nitrogen-fixing capacity of them was fairly high. The results from the previous studies have proved many species of the genus Klebsiella sp. showed their capacity in fixing nitrogen (Lin et al., 2012). Similar to Ochrobactrum sp. (Ngom et al., 2004) and Citrobacter sp. (Neilson, 1976). Besides, the nitrogen fixation capacity of Microbacterium neimengense and Olivibacter jilunii has not been found in any publication.

Finally, IAA production was detected via indole3-pyruvic acid and indole-3-acetic aldehyde pathway with biochemical reactions from tryptophan (Patten, Glick, 1996). The results showed that five selected bacteria in this study showed their high capactiy in IAA synthesis in the liquid medium containing tryptophan $\left(100 \mathrm{mg} \mathrm{L}^{-1}\right)$. This result was similar to other previous studies, indicating that Klebsiella sp. (Lin et al., 2012), Citrobacter freundii (Samina et al., 2010) and Ochrobactrum ciceri (Imran et al., 2015) produced high amounts of IAA in liquid medium containing tryptophan $\left(100 \quad \mathrm{mg} \mathrm{L}^{-1}\right)$. However, the previous studies in the IAA producing capacity of Olivibacter jilunii and Microbacterium neimengenes have not proved yet.

\section{CONCLUSION}

Five silicate solubilizing bacteria in this study, Microbacterium neimengense MCM_15, Olivibacter jilunii PTST_30, Citrobacter freudii RTTV_12, Klebsiella aerogenes LCT_01, and Ochrobactrum ciceri TCM_39 showed their most efficiency in silicate solubilization in liquid medium under following environmental conditions including $\mathrm{pH} 7$,
$\mathrm{NaCl} 0.0 \%$ and temperature $35^{\circ} \mathrm{C}$. Moreover, these five selected bateria still had fairly good in silicate solubilization even under other environmental conditions of $\mathrm{pH} \mathrm{3,5}$ or 9 , salt content $(\mathrm{NaCl})$ of $0.5 \%$ and temperature at $25^{\circ} \mathrm{C}$ or $45^{\circ} \mathrm{C}$. Beside the function in silicate solubilization, these five bacteria had also other functions like nitrogen fixation, phosphate solubilization mainly for $\mathrm{Ca}_{3}\left(\mathrm{PO}_{4}\right)_{2}$ and IAA synthesis in liquid media. Therefore, these five collected bacteria have broad potential in producing bio-fertilizers to enhance crop growth and yield.

\section{REFERENCES}

Bold HC (1949) The morphology of Chlamydomonas chlamydogama sp. nov.. Bull Torrey Bot Club 76: 101108.

Chen K, Tang SK, Wang GL, Nie GX, Li QF, Zhang JD, Li WJ, Li SP (2013) Olivibacter jilunii sp. nov., isolated from DDT-contaminated soil. Int J Syst Evol Microbiol 63: 1083-1088.

Gao M, Wang M, Zang YC, Zou XL, Xie LQ, Hu HY, Xu J, Gao JL, Sun JG (2013) Microbacterium neimengense sp. nov., isolated from the rhizophere of maize. Int J Syst Evol Microbiol 63: 236-240.

Hadi F, Mousavi A, Noghabi KA, Tabar HG, Salmanian $\mathrm{AH}$ (2013) New bacterial strain of the genus Ochrobactrum with glyphosate-degrading activity. $J$ Environ Sci Health 48: 208-213.

Hallmark CT, Wilding LP, Smeck (1982) Chemical and Microbiological Properties. In Page AL, eds. Methods of Soil Analysis. Madison: 263-274.

Imran A, Mirza MS, Shah TM, Malik KA, Hafeez FY (2015) Differential response of kabuli and desi chickpea genotypes toward inoculation with PGPR in different soils. Front Microbiol 6: 1-14.

Jacob JH, Irshaid FI (2012) Biochemical and molecular taxonomy of a mild halophilic strain of Citrobacter isolated from hypersaline environment. Res J Microbiol 7: 219-226.

Keevil CW, Hough JS, Cole JA (1977) Prototrophic growth of Citrobacter freudii and the biochemical basis for its apparent growth requirements in aerated media. $J$ Gen Microbiol 98: 273-276.

Khan M, Zaidi A, Ahmad E (2014) Mechanism of phosphate solubilization and physiological functions of phosphate-solubilizing microorganisms. In Khan MS, Zaidi A, Musarrat J, eds. Phosphate solubilizing microorganisms: principles and application of microphos technology. Springer International Switzerland: 31-62.

Khan MS, Zaidi A, Wani PA, Oves M (2009) Role of plant 
growth promoting rhizobacteria in the remediation of metalcontaminated soils. Environ Chem Lett 7: 1-19.

Liang Y, Sun W, Zhu YG, Christie P (2007) Mechanisms of silicon-mediated alleviation of abiotic stresses in higher plants. Environ Pollut 147: 422-428.

Lin L, Li Z, Hu C, Zhang X, Chang X, Chang S, Yang L, Li Y, An Q (2012) Plant growth-promoting nitroge-fixing Enterobacteria are in association with sugarcane plants growing in Guangxi, China. Microbes Environ 27: 391398.

Neilson AH, Sparell L (1976) Acetylence reduction (nitrogen fixation) by Enterobacteriaceae isolated from paper mill process waters. Appl Environ Microbiol 32: 197-205.

Ngom A, Nakagawa Y, Sawada H, Tsukahara J, Wakabayashi S, Uchiumi T, Nuntagij A, Kotepong S, Suzuki A, Higashi S, Abe M (2004) A novel symbiotic nitrogen-fixing member of the Ochrobactrum clade isolated from root nodules of Acacia mangium. $J$ Gen Microbiol 50: 17-27.

Osman AG (2009) Study of some characteristics of silicate bacteria. J Sc Tech 10: 27-35.

Patten CL, Glick BR (1996) Bacterial biosynthesis of indole-3-acetic acid. Can J Microbiol 42: 207-220.

Samina M, Baig DN, Lazarovits G (2010) Genetic and phenotypic diversity of plant growth promoting rhizobacteria isolated from sugarcane plants growing in Pakistan. J Microbiol Biotechnol 20: 1614-1623.

Sheng FX, Zhao F, He YL, Qiu G, Chen L (2008) Isolation and characterization of silicate mineral solubilizing Bacillus globisporus Q12 from the surface od weathered feldspar. Can J Microbiol 54: 1064-1068.

Toribio-Jiménez J, Rodríguez-Barrera MA, HernándezFlores G, Ruvacaba-Ledezma JC, Castellanos-Escamilla M, Romero-Ramirez Y (2017) Isolation and screening of bacteria from Zea mays plant growth promoters. Rev Int Contam Ambie 33: 143-150.

Tran Vo Hai Duong, Nguyen Khoi Nghia (2018) Isolation and selection silicate solubilizing bacteria from many various habitats. TNU J Sci Technol 180: 9-14.

Vasanthi N, Saleena LM, Raj SA (2012) Silicon in day today life. World Appl Sci J 17: 1425-1440.

\section{ĐÁNH GIÁ MộT SỐ ĐĂC TÍNH SINH LÝ CỦA NĂM DÒNG VI KHUẢN HÒA TAN KHOÁNG SILIC ĐƯợC PHÂ̂N LậP TƯ CÁC Hệ SINH THÁI KHÁC NHAU}

\section{Trần Võ Hải Đường ${ }^{1}$, Nguyễn Khởi Nghĩa ${ }^{2}$}

${ }^{I}$ Viện Nghiên cưu và Phát triển Công nghệ Sinh học, Truò̀ng Đại hoc Cần Tho, Thành phố Cần Tho'

${ }^{2}$ Bộ môn Khoa học Đất, Khoa Nông nghiệp, Truờng Đại học Cần Tho', Thành phố Cần Tho'

\section{TÓM TẮT}

Vi khuẩn hòa tan khoáng silic $(\mathrm{Si})$ đóng vai trò quan trọng trong hòa tan khoáng Si trong đất góp phần gia tăng sinh trưởng và năng suất cũng như tăng cường khả năng chống chịu với các điều kiện môi trường bất lợi của cây trồng. Mục tiêu của nghiên cứu này nhằm đánh giá một số đặc tính sinh lý như $\mathrm{pH}$, nồng độ muối $\mathrm{NaCl}$, nhiệt độ môi trường, khả năng hòa tan lân, cố định đạm và tổng hợp IAA trong môi trường lỏng của năm dòng vi khuẩn hòa tan khoáng Si tốt nhất. Môi trường dịch đất lỏng có chứa $0,25 \%$ magnesium trisilicate được sử dụng để đánh giá khả năng hòa tan khoáng $\mathrm{Si}$ của năm dòng vi khuẩn dưới ảnh hưởng của $\mathrm{pH}$, nồng độ muối và nhiệt độ. Ngoài ra, khả năng hòa tan lân, cố định đạm và tổng hợp IAA của năm dòng vi khuẩn tuyển chọn được kiểm tra lần lượt trong các môi trường NBRIP, Burk's và NBRIP bổ sung $100 \mathrm{mg} \mathrm{L}^{-1}$ tryptophan. Kết quả của nghiên cứu cho thấy năm dòng vi khuẩn hòa tan khoáng Si tốt nhất ở $\mathrm{pH} 7,0$, nồng độ muối $\mathrm{NaCl}$ $0,0 \%$ và nhiệt độ $35^{\circ} \mathrm{C}$. Hơn nữa, trong môi trường có nồng độ muối $0,5 \%$ các dòng vi khuẩn này vẫn hòa tan khoáng Si khá cao. Mặt khác, năm dòng vi khuẩn tuyển chọn cũng hòa tan hiệu quả 3 nguồn lân khó tan gồm $\mathrm{Ca}_{3}\left(\mathrm{PO}_{4}\right)_{2}, \mathrm{AlPO}_{4}$ và $\mathrm{FePO}_{4}$ trong môi trường lỏng với hàm lượng lần lượt đạt $105,8-928,7 \mathrm{mg}_{2} \mathrm{O}_{5} \mathrm{~L}^{-1}, 33$,9$49,6 \mathrm{mg} \mathrm{P} \mathrm{P}_{5} \mathrm{~L}^{-1}$ và $1,94-34,1 \mathrm{mg} \mathrm{P} \mathrm{P}_{2} \mathrm{O}_{5} \mathrm{~L}^{-1}$, cố định đạm với hàm lượng dao động từ $1,37-5,09 \mathrm{mg} \mathrm{NH}_{4}{ }^{+} \mathrm{L}^{-1}$ sau 2 ngày nuôi cấy. Cuối cùng, chúng còn có khả năng tổng hợp IAA khá cao và dao động 4.85-51.5 mg IAA $\mathrm{L}^{-1}$. Như vậy, năm dòng vi khuẩn tuyển chọn trong nghiên cứu này không chỉ hòa tan hiệu quả khoáng Si mà còn có chức năng gia tăng sinh trưởng và năng suất cây trồng.

Tù̀ khóa: cố định đạm, đặc tính sinh lý, hòa tan lân, nồng độ muối, tổng hợp IAA, vi khuẩn hòa tan khoáng silic 